\title{
In Vitro Cytotoxic Potential and Apoptotic Activity of Bufadienolide-rich Fraction from Leaves of Kalanchoe mortagei against Human HeLa Cancer Cells
}

\author{
Research Article
}

\author{
Fátima Solís Suárez ${ }^{1}$, Alethia Muñiz Ramirez ${ }^{2}$, \\ Rebeca López-Marure ${ }^{3}$, Rosa Martha Pérez Gutiérrez ${ }^{*}$
}

\author{
1. Departamento de Alimentos. Escuela Nacional de Ciencias Biológicas. Instituto Politécnico Nacional (IPN), \\ Carpio S/N, CP 11311, Ciudad de México. \\ 2. CONACyT-IPICYT/CIIDZA. Camino a la Presa San José 2055, Lomas 4a Sección, CP 78216, San Luis Potosí, \\ México. \\ 3. Departamento de Fisiología. Instituto Nacional de Cardiología Ignacio Chávez. Juan Badiano 1, CP 14080 \\ Tlalpan, Ciudad de México. \\ 4. Laboratorio de Investigación de Productos Naturales. Escuela Superior de Ingeniería. \\ Química e Industrias Extractivas. Instituto Politécnico Nacional (IPN) Unidad \\ Profesional Adolfo López Mateos S/N Av. CP 07758, Ciudad de México.
}

\begin{abstract}
Objective: The aim of this study was to evaluate the chemical composition as well as to assess the cytotoxicity of Kalanchoe mortagei. Materials and Methods: The plant chemical composition was determined by HPLC coupled to mass spectrometer. The cytotoxicity of methanol extract from leaves of Kalanchoe mortagei (KB) was carried out against human cervical cancer cells (HeLa), breast cancer (MCF-7), brain cancer (U373), breast adenocarcinoma (MDA-MB-231) and umbilical vein endothelial cells (HUVEC) by 3-(4,5-dimethylthiazol2-yl)-2,5-diphenyltetrazolium bromide (MTT) assay. KB was added at various concentrations of $6.25,12.5,25$, 50,100 and $200 \mu \mathrm{g} / \mathrm{ml}$. In addtion, cell morphological changes and apoptosis were also evaluated. Results: A bufadienolides-rich fraction (BRF) containing nine bufadienolides was identified by HPLC/MS which to significantly reduce proliferation of HeLa cells. Bufadienolides identified included 3 $\beta$-Acetate Hellebrigenin, Bufotalinin, 19-Oxo-bufalin, Hellebrigenin, Monohydroxy-bufotalin, 19-oxo-desacetylcinobufagin, $1 \beta-$ Hidroxybufalin, Bufalin, and 3-Dehydroxy cinobufagin. Discussion \& Conclusion: K. mortagei contains bufadienolides with specific cytotoxic activity on cancer cells without affect to normal cells, suggesting that its consumption could be considered as a potential therapy against cancer.
\end{abstract}

Keywords: Bufadienolides, Kalanchoe mortagei, apoptosis, cytotoxic .

\section{Introduction}

After cardiovascular diseases, cancer represents the second cause of death for morbidity and mortality worldwide. In 2015, 8.8 million of people died from cancer according to World Health Organization and predicted to increase to over 24 million in 2035 (1). The most common types of cancer in men in order of incidence of major to minor are prostate, lung, colorectal, stomach and liver cancer; and in woman, breast, lung, cervix, thyroid, colon and stomach cancer (2). The type of treatment depends on the type of cancer and its status. The types most common are a combination of surgery with chemotherapy and-or radiation, immunotherapy, hormone or targeted therapy

\footnotetext{
*Corresponding Author:

Rosa Martha Perez Gutierrez

Laboratorio de Investigación de Productos Naturales. Escuela Superior de Ingenieria Quimica e Industrias Extractivas. Instituto Politecnico Nacional (IPN) Unidad Profesional Adolfo Lopez Mateos S/N Av. cp 07758.
}

Instituto Politécnico Nacional Ciudad de Mexico
(3); however, these therapies are not always successful, besides they are not specific against tumor cells damaging to healthy tissues and have strong adverse side effects reducing the quality of life for patients (4). Thus, it is very important to consider plants as a source to discover new potent anticancer drugs with side effects. Recently, extracts and phytochemicals from plants such as medicinal herbs, vegetables and fruits have had important attention due to their ability to modulate apoptosis signaling, may be potential anticancer drugs (5). Several secondary metabolites content in the medicinal plants are known to have anticancer effect inducing apoptosis in several cancer cell lines. Antitumor research is focused to find new treatments, especially from natural origin, which have no negative effects on normal cells. Actually in the chemotherapy, around $75 \%$ of prescribed drugs worldwide derive from plants (6).

The genus Kalanchoe (K) belongs to the family of the Crassulaceae, also known as Cotelydon or Bryophyllum (7). This plant is a perennial succulent herb native of Madagascar, that grows wild and are widely used in traditional medicinal in tropical America, 
Australia, Africa and China mainly (8). Previous studies reported that extracts from some Brophyllum exhibit anti -inflammatory (9), cardiovascular (10), antihyperglycemic (11), analgesic (12), antiulcer (13), antimicrobial and anticancer effects (14). A cytotoxic activity on human tumor cell lines was attributed to bufadienolides from the aerial parts of $K$. gracilis (6). Other species such as $K$. tubiflora and $K$. daigremontiana have shown also anti-tumor activity caused by bufadienolides $(15,16)$. K. mortagei. is commonly cultivated as an ornamental plant in Mexico and is widely used in cancer therapy. It is our knowledge, no literature regarding the cytotoxic activity or phytochemical composition of $K$. mortagei. In this study we focused to evaluate the cytotoxic effect of a bufadienolides-rich fraction from $K$. mortagei on cancer cell line.

\section{Materials and Methods Materials}

Acetonitrile $(\mathrm{MeCN})$ (gradient-grade for $\mathrm{LC}$ ), formic acid of p.a. grade and methyl-thiazolyltetrazolium dye (MTT), DMSO, annexin-V FITC apoptosis kit, propidium iodide, cycloheximide (CHX, $>99 \%$ purity) and etoposide were purchased in (Sigma -Aldrich, St. Louis, MO, USA). Milli-Q water was prepared in-house. RPMI 1640, McCoys medium base and streptomycin/penicillin stock solution were purchased from Gibco, Life Technologies (Carlsbad, CA, USA). Heat inactivated foetal calf serum from Biochrom, Berlin, Germany. Nucleosil C18 column $(4.0 \mathrm{~mm} \times 250 \mathrm{~mm}, 5 \mathrm{~m})$ from Macherey-Nagel, Duren, Germany. Cytotoxicity Detection Kit Plus (Roche, Grenzach-Wyhlen, Germany). Sephadex LH20 , and silica gel (200-400 mesh) were used for the column chromatography, and pre-coated silica gel (60 F -254) in plates were used for the TLC analyses which were purchased in Merck (Mexico).

\section{Plant material}

The leaves of $K$. mortagei were collected from Curungueo, in the municipality of Zitácuaro Michoacan State in Mexico in August 2015. These plants were identified and authenticated by the Department of Botany of the National School of Biological SciencesIPN, a voucher specimen was deposited in the Department of plant taxonomy.

\section{Plant extract}

The dried leaves of $K$. mortagei $(100 \mathrm{~g})$ were extracted with hexane (KAH), chloroform (KAC) and methanol $(\mathrm{KAM})$ two times $(21 \times 2)$ under reflux. After filtration and evaporation of the solvent at reduced pressure extracts were tested.

In another experiment the leaves were air-dried in shade at room temperature and granded into powder $(800 \mathrm{~g})$. Extraction was performed in Soxtler apparatus with methanol for $3 \mathrm{hrs}$ and then the solvent was evaporated until half volume. An equal volume of water was added while heating on $60^{\circ} \mathrm{C}$ and placed on refrigerator for $24 \mathrm{hrs}$. The precipitated material was discarded and supernatant was used for this study.

\section{Obtaining a bufadienolide-rich fraction}

Supernatant was concentrated to dryness under reduced pressure to obtain slurry $(48 \mathrm{~g})$. The slurry was dissolved in minimum amount of methanol and was adsorbed on silica gel (120-430 mesh). The slurry was subjected to a silica gel column eluted with chloroform/ methylene chloride 2:1 gradient system to yield 11 fractions (F-1 to F-11). The elutes were examined by TLC and each one of them were determined cytotoxic activity. When comparing the cytotoxic activity of the fractions F-1 to F-11 found that F10 possess a potent effect which was bufadienolides- rich (BRF).

\section{HPLC/MS assay}

The analyses were performed using a Shimadzu HPLC system (Shimadzu, Kyoto, Japan) equipped with an SPD-M10A VP diode array detector, LC10AD VP binary pump, an autosampler, a DGU-14A degasser and SCL-10A VP system controller. The samples were separated on a Nucleosil C18 column. The mobile phase consisted of $0.1 \%$ formic acid in water (solvent A) and acetonitrile (solvent B), with the gradient elution as follows: $0-5 \mathrm{~min}, 20 \%$ to $35 \% \mathrm{~B}$; 5 $-20 \mathrm{~min}, 35 \%$ to $50 \% \mathrm{~B} ; 20-30 \mathrm{~min}, 50 \%$ to $95 \% \mathrm{~B}$; $30-35 \mathrm{~min}$, held at $95 \% \mathrm{~B} ; 35-40 \mathrm{~min}$, balanced to

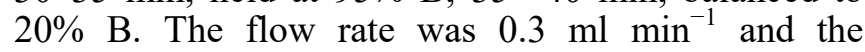
temperature of the column was maintained at $30^{\circ} \mathrm{C}$ and an injection volume of $4 \mu 1$ was used. All the samples were monitored at $296 \mathrm{~nm}$. In addition, mass detection was performed in positive ion mode in a range of $150-1000 \mathrm{~m} / \mathrm{z}$. The parameters for LC-MS analysis were as follows: Curtain gas, 12 units; nebulizer gas, 8 units; entrance potential, $5 \mathrm{~V}$, focusing potential, $200 \mathrm{~V}$; declustering potential, $60 \mathrm{~V}$ and ionization voltage, $4000 \mathrm{~V} .[\mathrm{M}+\mathrm{H}]+$ ions were selected and subjected to collision-induced dissociation (CID) tandem mass spectrometry (MS/MS) analysis using nitrogen as the collision gas. The optimized parameters for MS/MS analysis were as follows: Collision cell exit potential, $15 \mathrm{~V}$, collision energy, 30 $\mathrm{eV}$ and collision gas, 2 units. Data processing was performed using Xcalibur 3.0, Metworks 1.3 and Mass Frontier 7.0 software packages.

\section{Cell culture}

Cell lines were obtained from the ATCC (American Type Culture Collection, Rockwille, MD, USA). HeLa (cervical cancer cells), MCF-7 (human breast cancer), U373, (brain cancer), MDA-MB-231 (breast adenocarcinoma) and HUVEC (human umbilical vein endothelial cells) were cultured in U-2OS in McCoys medium and RPMI 1640 medium supplemented with $10 \%$ heat inactivated foetal calf serum, $100 \mathrm{lg} / \mathrm{ml}$ streptomycin and $100 \mathrm{U} / \mathrm{ml}$ penicillin and 5\% CO2 at 37 ${ }^{\circ} \mathrm{C}$. All cell lines were transferred to six-well plates at 4X105/well $18 \mathrm{~h}$ before assay set-up. Cells were treated at different duration and concentrations of samples and then subjected to analysis.

\section{Cell viability}

Cell viability was evaluated mediating the reduction of 3-(4,5-dimethylthiazol-2-yl)-2,5-diphenyltetrazolium bromide (MTT) to water-insoluble formazan. For this, 
cells were exposed to diverse concentrations of the different crude extracts $(6.25,12.5,25,50,100$ and 200 $\mu \mathrm{g} / \mathrm{ml})$ for 48 and $72 \mathrm{~h}$; after treatment, cells were incubated with $20 \mu \mathrm{l}$ of a stock solution of MTT (5 mg/ $\mathrm{ml}$ ) for $4 \mathrm{~h}$ and optical density was measured at $570 \mathrm{~nm}$ in a microplate spectrophotometer (Benchmark Plus, BIO-RAD).

\section{Crystal violet staining}

HeLa cells were exposed to $6.25,12.5,25,50,100$ and $200 \mu \mathrm{g} / \mathrm{ml}$ of KAM for $72 \mathrm{~h}$. After, cells were washed three times with de-ionized water and stained for $20 \mathrm{~min} 0.1 \%$ crystal violet solution (in $200 \mathrm{mM}$ phosphoric acid buffer at $\mathrm{pH}$ 6). Cells were washed exhaustively to eliminate the color non-incorporated and after, cells were analyzed in an inverted microscope (Olympus, model CKX41, BioRad, Hercules, CA, USA) and photographs were taken at a $20 \mathrm{X}$ magnification.

\section{Cell death determination}

Phosphatidylserine translocation was used to determine apoptosis. This was evaluated using the annexin-V-fluos stainning kit. Cells were treated with all crude extracts for $48 \mathrm{~h}$, then washed with PBS and centrifuged at $200 \mathrm{rpm}$ for $5 \mathrm{~min}$. Each cell pellet was resuspended in $100 \mu \mathrm{l}$ of labeling solution $(20 \mu \mathrm{l}$ annexin-V-fluos labeling reagent in $1 \mathrm{ml}$ Hepes buffer [10 mM Hepes/NaOH, pH 7.4, 140 mM NaCl, $5 \mathrm{mM}$ $\mathrm{CaCl} 2$ ], $1 \mu \mathrm{g} / \mathrm{ml}$ propidium iodide) and incubated for 15 min. After, samples were washed with Hepes buffer, pellets were suspended in $400 \mu$ of Hepes buffer and the samples were analyzed in a flow cytometer (FACSCalibur, Becton Dickinson) at $488 \mathrm{~nm}$ (excitation) and $515 \mathrm{~nm}$ bandpass filter for fluorescein detection, and a filter $>560 \mathrm{~nm}$ for propidium iodide detection. Cell analysis was performed using the Cell
Quest Software Program. Cells stained with annexinV-fluos alone were considered apoptotic, whereas double stained cells (annexin-V-fluos + propidium iodide) were considered late apoptotic or necrotic.

\section{Statistical analysis}

Three independent experiments was performed for each condition. The results were expressed as the mean \pm standard deviation (SD). Comparisons between groups were tested by one-way analysis of variance (ANOVA) and post hoc Tukey's pairwise comparison using GraphPad Prism version 6 and Minitab version 17. Differences were considered statistically significant when $\mathrm{p} \leq 0.05$.

\section{Results \\ Analysis of cell viability}

The three extracts obtained from K. mortagei were hexane (KAH), chloroform (KAC) and methanol (KAM) their cytotoxic effect was evaluated on four cancer cell lines HeLa, MCF-7, U373 and MDA-MB-231 by MTT assay. The inhibitory concentrations $50 \%$ of viability (IC50) were calculated from concentration-response curve. KAM shown a growth inhibitory effect toward HeLa and U373 cells with an IC50 of $<6.25$ and $55 \mu \mathrm{g} / \mathrm{ml}$, respectively (Table 1). KAH and KAC did not show effect on the viability at lower concentrations than $200 \mu \mathrm{g} / \mathrm{ml}$ in all cell lines used. The criteria of cytotoxicity for the samples, was established by the U.S. National Cancer Institute, which is IC50 < 20 $\mu \mathrm{g} / \mathrm{ml}$ in the preliminary assay (17). Among the extracts the most cytotoxic was KAM and the less cytotoxic was KAH. It has been shown that extracts obtained from Kalanchoe with polar solvents are more efficient to decrease viability compared with the obtained with non-polar solvents.

Table 1. Sensitivity $\left(\mathrm{IC}_{50}\right)$ of different cancer cell lines to extracts obtained from Kalanchoe mortagei

\begin{tabular}{|c|c|c|c|c|}
\hline \multicolumn{5}{|c|}{$\mathrm{IC}_{50}(\mu \mathrm{g} / \mathrm{mL})$} \\
\hline Extract & HeLa & MCF-7 & U373 & MDA-MB-231 \\
\hline KAH & $>200$ & $>200$ & $>200$ & $>200$ \\
\hline KAC & $>200$ & $>200$ & $>200$ & $>200$ \\
\hline KAM & $<6.25$ & $>200$ & 55 & $>200$ \\
\hline
\end{tabular}

Sensitivity $\left(\mathrm{IC}_{50}\right)$ of different cancer cell lines to extracts obtained from $K$. mortagei. Cancer cells were exposed to $6.25,12.5,25,50,100$ and $200 \mu \mathrm{g} / \mathrm{mL}$ of the hexane (KAH), chloroform (KAC) and methanol (KAM) leaves extracts and cell viability was evaluated by MTT reduction after $72 \mathrm{~h}$.

\section{Effect of K. mortagei extracts on HUVEC cells viability}

To test of viability of normal cells was also evaluated on HUVECcells. The results indicated that all extracts did not affect cell viability; in contrast, an increase of proliferation over $100 \%$ when the cells were treated at concentration of $6.25-50 \mu \mathrm{g} / \mathrm{ml}$ with $\mathrm{KAH}, \mathrm{KAC}$ and $\mathrm{KAM}$ was observed (Figure 1). KAM increased the cell viability in $50 \%$ compared with control cells $(\mathrm{p} \leq 0.05)$ at the concentration of $12.5 \mu \mathrm{g} / \mathrm{ml}$, which was much stronger that the other extracts. To taking in consideration these results in the next experiments only HeLa cells and KAM were used. 


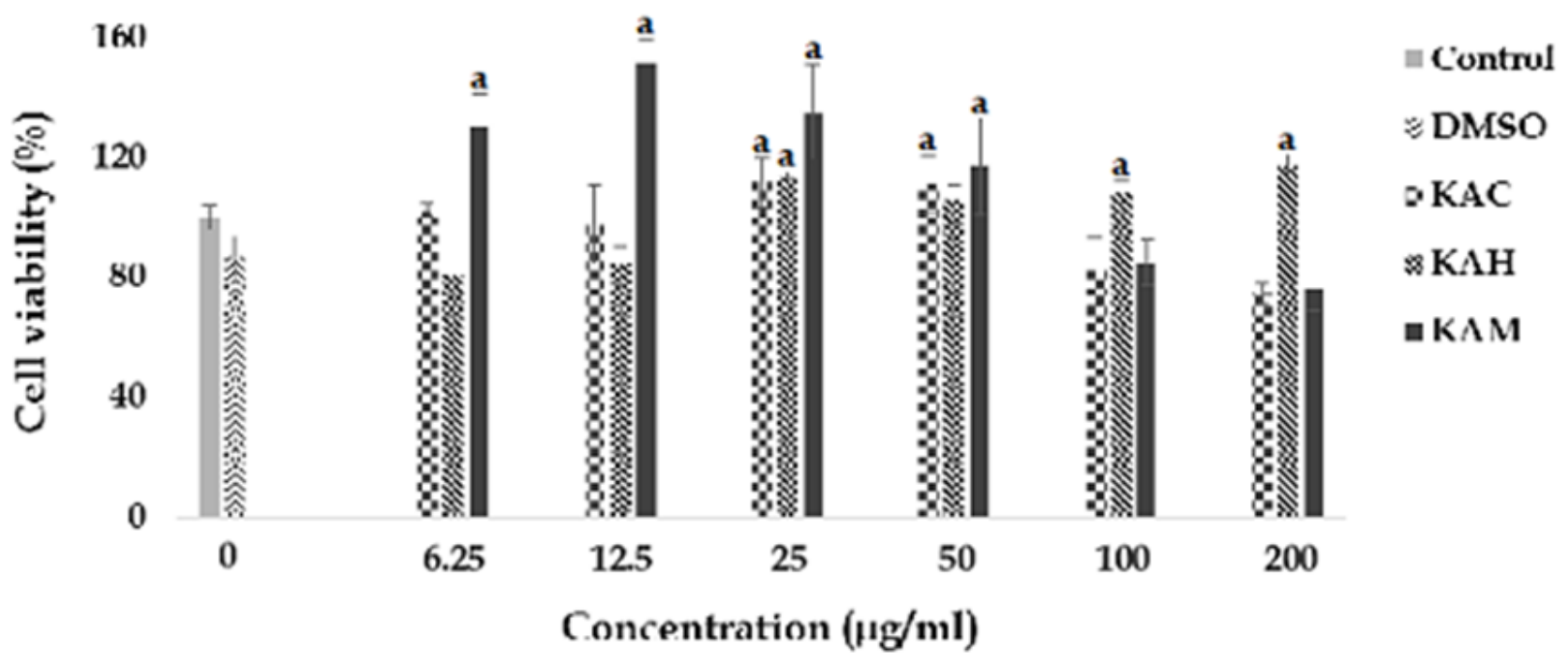

Figure 1. Effect of the extracts hexane (KAH), chloroform (KAC) and methanol (KAM) on the viability of HUVEC. Cells were cultured with different concentrations of extracts $(6.25,12.5,25,50,100$ and $200 \mu \mathrm{g} / \mathrm{ml})$ for 72 $\mathrm{h}$ and cell viability was determined by MTT reduction. DMSO was used as a vehicle. The results are expressed as percentages with respect to the control without treatment (100\%). Data represent the mean \pm SD of a representative experiment of three performed in an independent way $(n=3)$. Compared with control group $a=p \leq 0.05$.

\section{Effect of KAM treatment on cell morphology}

The change in cell morphology is the first effect of toxic compounds exposure to the cells, which is used for measuring toxicity levels providing preliminary data about the mechanism of cytotoxicity; therefore, cell morphology was also evaluated in HeLa cells, which were more sensitive to the effect induced by KAM, mediating crystal violet staining. The results showed a decrease of the cell number observed from $6.25 \mu \mathrm{g} / \mathrm{ml}$ and with a maximum effect obtained at $200 \mu \mathrm{g} / \mathrm{ml}$ (Figure 2). Alterations on cell morphology such as detachment of cells from the well surface, rounding of cells, nuclear disintegration $(50 \mu \mathrm{g} / \mathrm{ml}$ ), augmented density of the cytoplasm (from 12.5 $\mu \mathrm{g} / \mathrm{ml}$ ), fragmentation and shrinkage of the cytoplasm and breaking of the cytoplasmic membrane (from $100 \mu \mathrm{g} / \mathrm{ml}$ ) were observed in exposed cells, compared with control cells (Figure 2). These morphological changes are characteristic of severe cell damage.
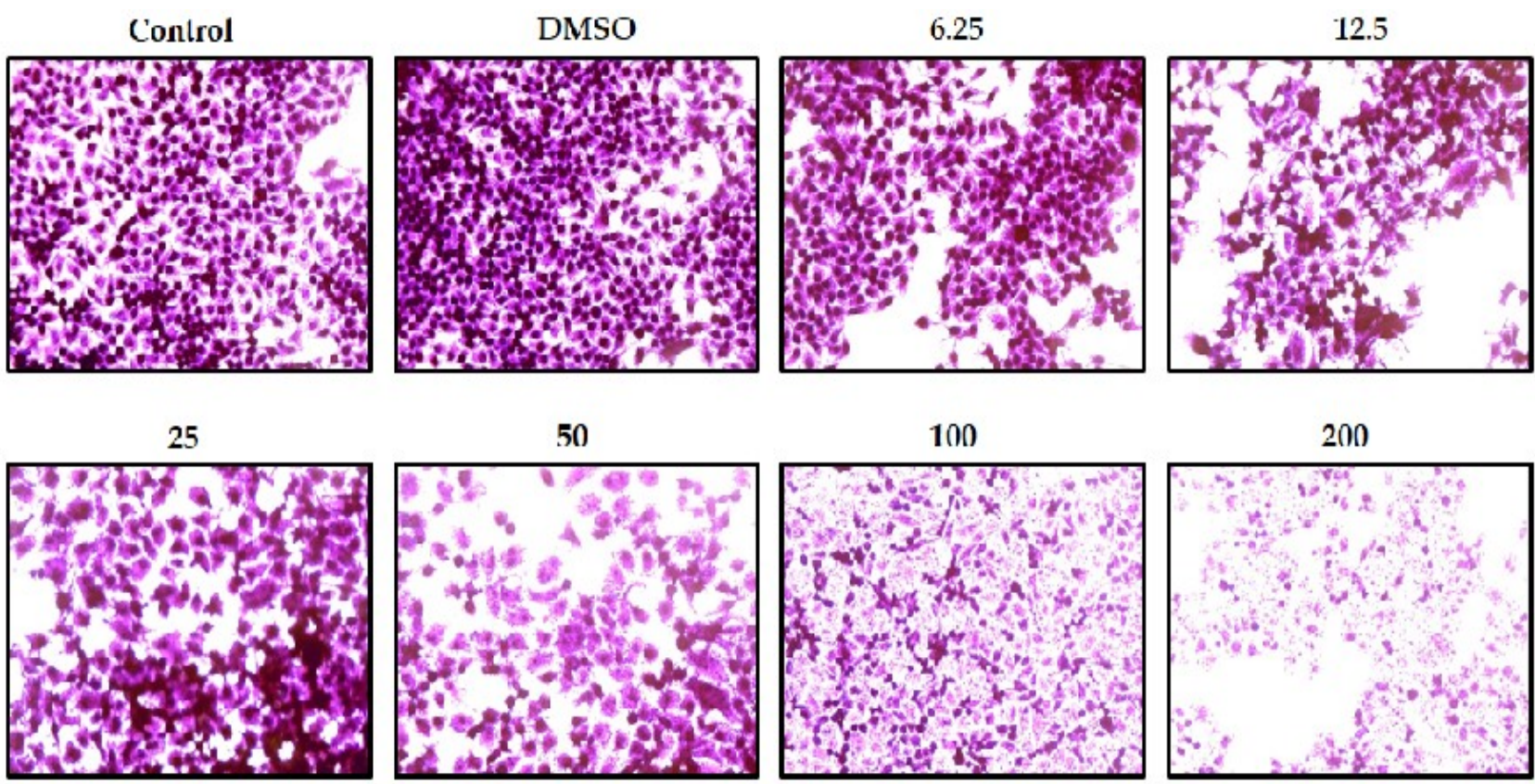

50

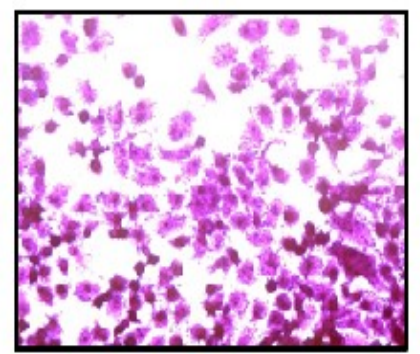

100

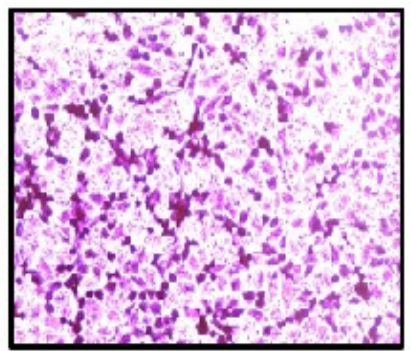

200

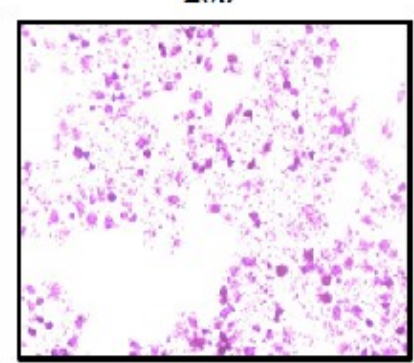

Figure 2. Effect of methanol extract (KAM) on the morphology of HeLa cells. Cell were cultured with 6.25, $12.5,25,50,100$ and $200 \mu \mathrm{g} / \mathrm{ml}$ of KAM for $72 \mathrm{~h}$ and cells were stained with crystal violet to observe morphology. Light microscopy micrographs were taken at a magnification of $20 \mathrm{X}$. 


\section{Effect of KAM and F10 on HeLa cell death}

Since damage in cells exposed to KAM was observed, the two best characterized types of cell death were evaluated by annexin- $\mathrm{V}$ assay and iodide propidium staining. Annexin- $\mathrm{V}$ protein is commonly used to detect in apoptotic cell surfaces phosphatidylserine molecules. However, the absorption and binding of nuclear DNA to propidium iodide can be used for differentiating necrosis of late stage apoptosis from early apoptosis. The results showed that concentrations of KAM from $25 \mu \mathrm{g} / \mathrm{ml}$ induced apoptosis (late and early) after $48 \mathrm{~h}$ of exposure and this effect was concentration dependent, reaching a $25 \%$ in comparison with control cells (Fig 3). No significant necrosis was observed with KAM, but the high apoptosis suggest a retarded cell proliferation in early stages of toxicity and that the major cytotoxicity mechanism of KAM is the apoptosis (Table 2).

Table 2. Effect of methanol extract (KAM) on the death of HeLa cells.

\begin{tabular}{|c|c|c|c|c|c|}
\hline \multirow[b]{2}{*}{ Treatment } & \multicolumn{4}{|c|}{ Percent (\%) } & \\
\hline & Alive & Early apoptosis & Lat & Necro & \\
\hline Control & 99.0 & & 0.2 & 0.4 & 0.4 \\
\hline Boiled cells & 10.9 & & $\overline{0.1}$ & 2.5 & 86.5 \\
\hline$\overline{\mathrm{DMSO}}$ & 97.7 & & 1.1 & 0.8 & 0.5 \\
\hline $6.25 \mu \mathrm{g} / \mathrm{mL}$ & 98.8 & & 0.4 & 0.3 & 0.5 \\
\hline 12.5 & 96.6 & & 1.3 & 1.3 & 0.7 \\
\hline 25 & 86.6 & & $4.5^{\mathrm{a}}$ & $5.2^{\mathrm{a}}$ & $3.7^{\mathrm{a}}$ \\
\hline 50 & 81.5 & & $6.8^{\mathrm{a}}$ & $9.1^{\mathrm{a}}$ & $2.6^{\mathrm{a}}$ \\
\hline 100 & 75.5 & & $7.4^{\mathrm{a}}$ & $14.7^{\mathrm{a}}$ & $2.4^{\mathrm{a}}$ \\
\hline 200 & 72.2 & & $10.8^{\mathrm{a}}$ & $15.0^{\mathrm{a}}$ & $2.0^{\mathrm{a}}$ \\
\hline
\end{tabular}

The results are expressed as percentages of a representative experiment of three performed in an independent way. Compared with control group $\mathrm{a}=\mathrm{p} \leq 0.05$
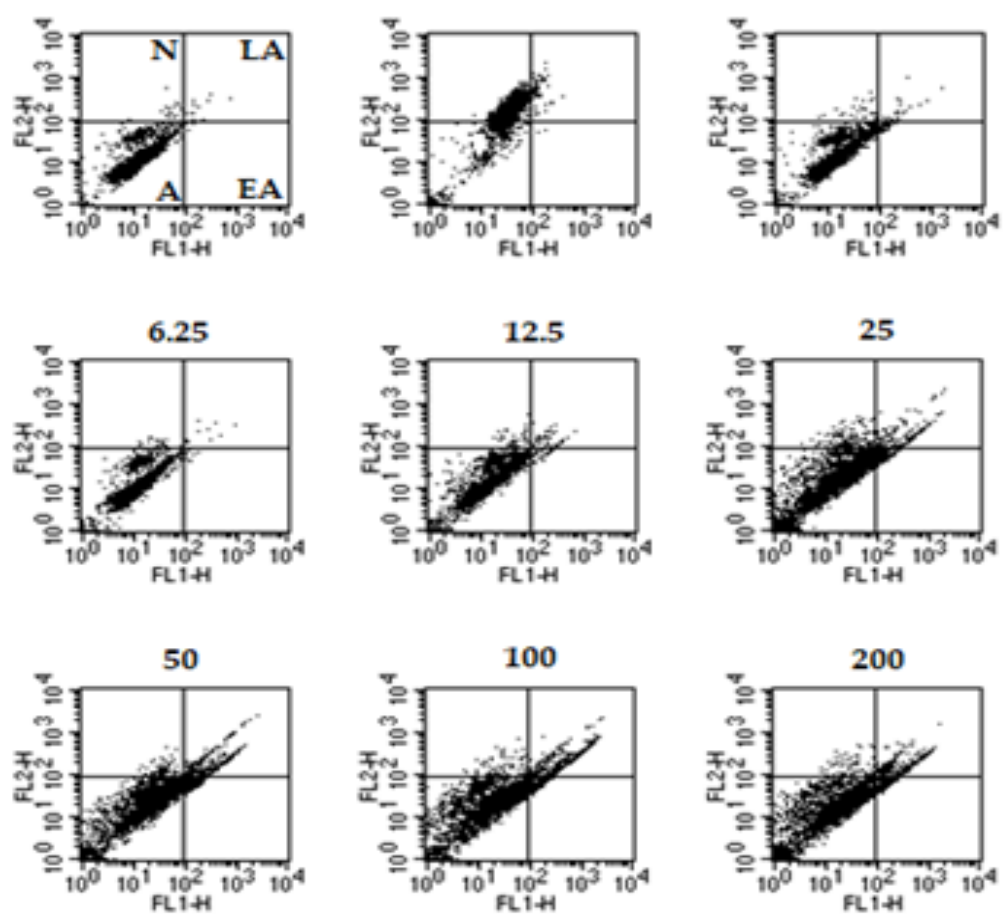

Figure 3. Effect of methanol extract (KAM) on the death of HeLa cells. Cells were cultured with different concentrations of extracts $(6.25,12.5,25,50,100$ and $200 \mu \mathrm{g} / \mathrm{ml})$ for $48 \mathrm{~h}$ and cell death was determined by annexin$\mathrm{V}$ assay and iodide propidium staining mediating flow cytometry. DMSO was used as a vehicle and boiled cells as a positive control of necrosis. In histograms are showed, where $\mathrm{A}=$ alive cells, $\mathrm{EA}=$ early apoptosis, LA = late apoptosis and $\mathrm{N}=$ necrosis. Compared with control group $\mathrm{a}=\mathrm{p} \leq 0.05$. 


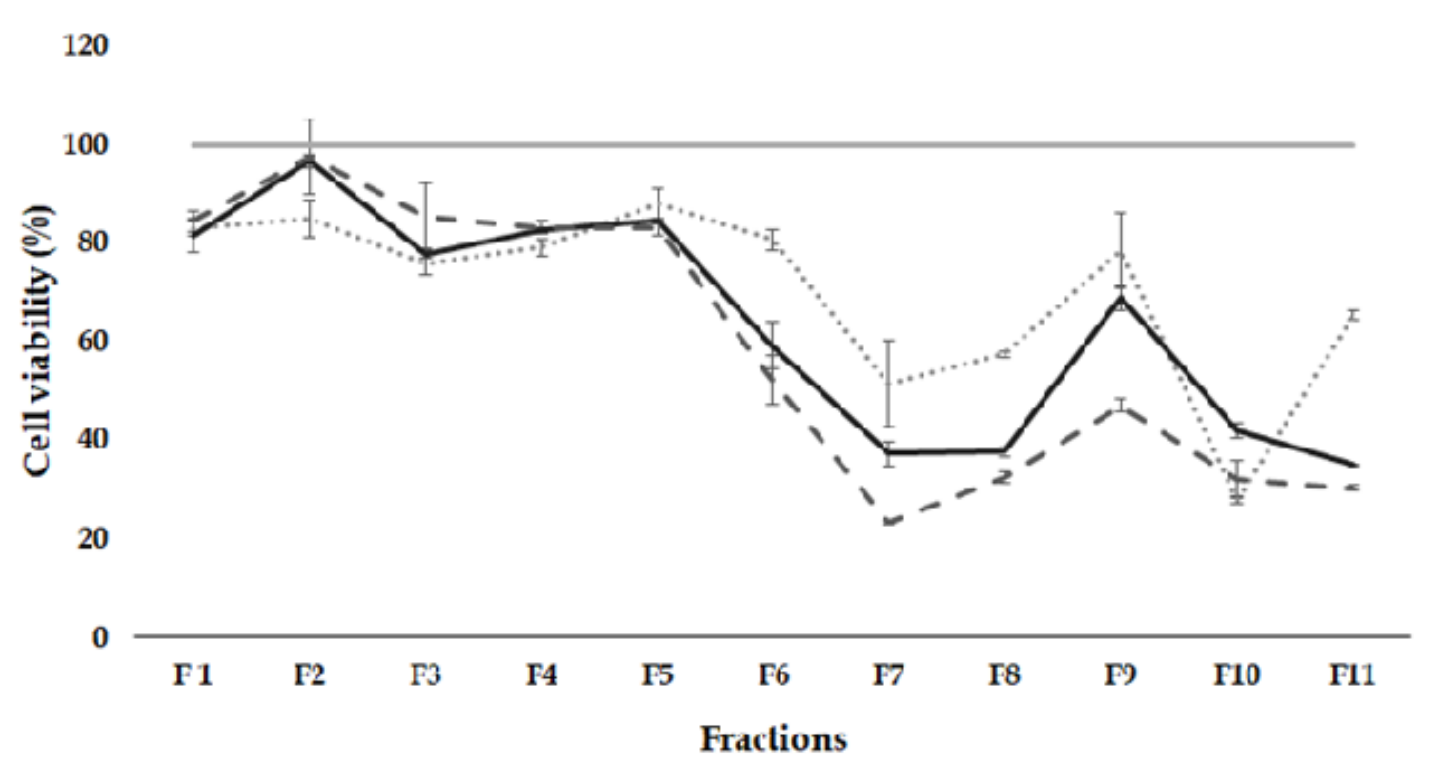

Figure 4. Effect of the 11 different fractions obtained from KAM on HeLa cells viability. KAM was fractionated by column chromatography and cells were cultured with $6.25,12.5$ and $25 \mu \mathrm{g} / \mathrm{mL}$ of each fraction for 72 $\mathrm{h}$ and cell viability was evaluated by MTT reduction. Data represent the mean $\pm \mathrm{SD}$ of a representative experiment of three performed in an independent way $(n=3)$. Compared with control group $a=p \leq 0.05$.
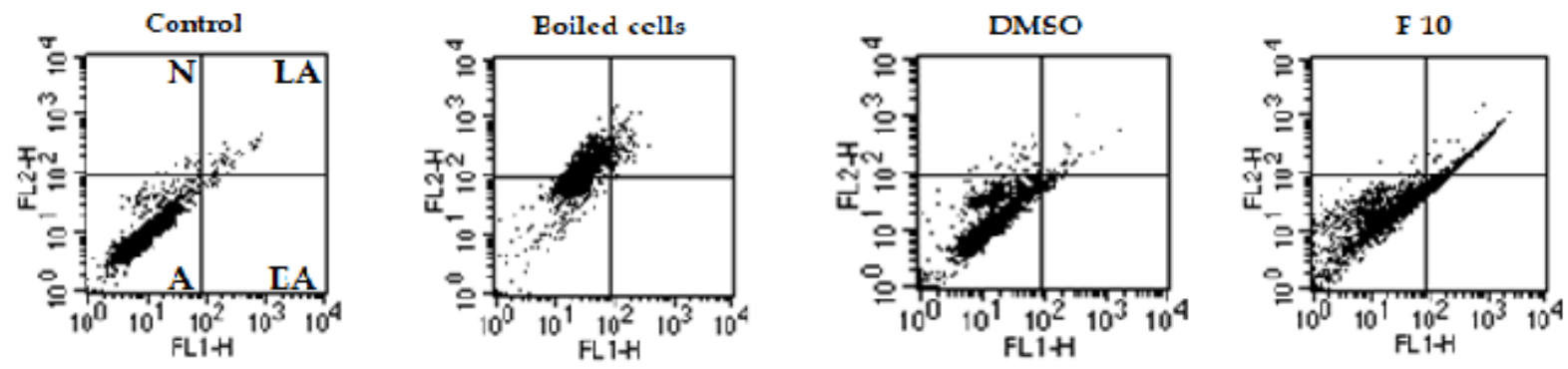

Figure 5. Effect of F10 on the death of HeLa cells. Cells were cultured with $25 \mu \mathrm{g} / \mathrm{ml}$ of F 10 for $48 \mathrm{~h}$ and cell death was determined by annexin- $\mathrm{V}$ assay and iodide propidium staining mediating flow cytometry. DMSO was used as a vehicle and boiled cells as a positive control of necrosis. In histograms are showed, where $\mathrm{A}=$ alive cells,

$\mathrm{EA}=$ early apoptosis, $\mathrm{LA}=$ late apoptosis and $\mathrm{N}=$ necrosis. Compared with control group $\mathrm{a}=\mathrm{p} \leq 0.05$.

Table 3. Effect of F10 from Kalanchoe mortagei on the death of HeLa cells.

\begin{tabular}{|l|l|l|l|l|}
\hline \multicolumn{5}{|c|}{ Percent (\%) } \\
\hline Treatment & Alive & Early Apoptosis & Late Apoptosis & Necrosis \\
\hline Control & 97.3 & 0.1 & 1.5 & 1.1 \\
\hline Boiled cells & $4.0^{\mathrm{a}}$ & 0.0 & $4.3^{\mathrm{a}}$ & $91.8^{\mathrm{a}}$ \\
\hline DMSO & 97.6 & 1.1 & 0.8 & 0.5 \\
\hline F10 & $73.6^{\mathrm{a}}$ & 2.3 & 22.4 & 1.8 \\
\hline
\end{tabular}

The results are expressed as percentages of a representative experiment of three performed in an independent way. Compared with control group $\mathrm{a}=\mathrm{p} \leq 0.05$.

\section{Identification of bufadienolides}

The compounds responsible for the cytotoxic activity of KAM were chromatographed and were identified by HPLC/MS, obtaining 9 bufadienolides previously reported (Table 4). Other studies with plants of several species of Kalanchoe indicate that bufadielonides are the responsible of the anticancer activity $(18,19)$. Five bufadienolides isolated from $K$. pinnata y $K$. daigremontiana leaves inhibited the viability of Raji cells (15). Hellebrigenin, a bufadienolide isolated from $K$. genera, induced DNA damage, mitochondrial alterations, arrest of the cell cycle and apoptosis (14). 
Table 4. Identification of bufadienolides in Kalanchoe mortagei by using HPLC/MS

\begin{tabular}{|c|c|c|c|c|c|c|}
\hline Num & Compound & $\begin{array}{c}\mathrm{Rt} \\
(\mathrm{min})\end{array}$ & $\%$ & $\mathrm{~m} / \mathrm{z}$ & $\begin{array}{l}\text { Molecular } \\
\text { Formula }\end{array}$ & $\mathrm{UV}(\mathrm{nm})$ \\
\hline 1 & Hellibrigenin & 0.6 & 25 & $\begin{array}{l}417[\mathrm{M}+\mathrm{H}], 476,458,399, \\
363,335\end{array}$ & $\mathrm{C}_{24} \mathrm{H}_{32} \mathrm{O}_{6}$ & 246 \\
\hline 2 & Bufotalin & 2.4 & 7.2 & $\begin{array}{l}415[\mathrm{M}+\mathrm{H}], 474,456,397, \\
379,351,333\end{array}$ & $\mathrm{C}_{24} \mathrm{H}_{30} \mathrm{O}_{6}$ & 249 \\
\hline 3 & 19-Oxo-bufalin & 2.7 & 11 & $\begin{array}{l}401[\mathrm{M}+\mathrm{H}], 460,442,418, \\
383,365,347,319\end{array}$ & $\mathrm{C}_{24} \mathrm{H}_{32} \mathrm{O}_{5}$ & 245 \\
\hline 4 & $3 \beta$-Acetato-hellebrigenin & 11.5 & 4.4 & $\begin{array}{l}459[\mathrm{M}+\mathrm{H}], 381,363,345, \\
335,289,255\end{array}$ & $\mathrm{C}_{26} \mathrm{H}_{34} \mathrm{O}_{7}$ & 219,276 \\
\hline 5 & Bufalin & 12.1 & 1.7 & $\begin{array}{l}387[\mathrm{M}+\mathrm{H}], 446,428,404, \\
369,351,333\end{array}$ & $\mathrm{C}_{24} \mathrm{H}_{34} \mathrm{O}_{4}$ & 244 \\
\hline 6 & Monohydroxybufotalin & 16.2 & 3.7 & $\begin{array}{l}461[\mathrm{M}+\mathrm{H}], 365,347,267, \\
251\end{array}$ & $\mathrm{C}_{26} \mathrm{H}_{36} \mathrm{O}_{7}$ & 214,254 \\
\hline 7 & 19-Oxo-desacetylcinobufagin & 19.6 & 14.9 & $\begin{array}{l}415[\mathrm{M}+\mathrm{H}], 456,474,397, \\
379,361,351,333\end{array}$ & $\mathrm{C}_{24} \mathrm{H}_{30} \mathrm{O}_{6}$ & 236 \\
\hline 8 & $1 \beta$-Hydroxybufalin & 21.3 & 17.5 & $\begin{array}{l}403[\mathrm{M}+\mathrm{H}], 462,444,385, \\
367,349,339,253\end{array}$ & $\mathrm{C}_{24} \mathrm{H}_{35} \mathrm{O}_{5}$ & 212,249 \\
\hline 9 & 3-Dehydroxycinobufagin & 36.6 & 1.0 & $\begin{array}{l}439[\mathrm{M}+\mathrm{H}], 397,379,361, \\
319,271\end{array}$ & $\mathrm{C}_{26} \mathrm{H}_{30} \mathrm{O}_{6}$ & 212,258 \\
\hline
\end{tabular}

\section{Discussion}

In the treatment of cancer and its prevention chemotherapy plays an important role; but cell resistance to the drugs, necessitate a constant amelioration in the treatments. In the last decade novel classes of chemotherapeutic drugs have been continuously studied, among natural compounds have led to new drug development. Several species of the generous Kalanchoe have shown antitumoral properties; however, the effect of aerial part of $K$. mortagei against different cancer cell lines have not been studied as yet. Thus, in the present investigation we extracted, purified and characterized a fraction anti-cancer from leaves of $K$. mortagei. Cell viability assay is an important study to measure the cellular response to toxicant or drug providing information on metabolic activities, cell survival and death (20).

Selective toxicity and efficacy are important requirements of cancer therapeutics. The ability of a drug to sparing normal cells and induce apoptosis of cancer cells is an important requirement in cancer treatment. Many drugs act on the immune system to fight cancer, and they should not have an unfavorable affect immune system. Hereby, the antiproliferative of all extracts were studied in primary cultures of normal endothelial cells. It was interesting to observe that KAM increased HUVEC proliferation at lower concentrations, and that higher concentrations did not affect cell viability, indicating its high selectivity. One work have reported similar results, where different extracts from $K$. pinnata, $K$. gastonis-bonnieri and K. flammea did not affect the viability of primary cultures of lymphocytes (21).

HeLa cells exposed to KAM change to round shape and detached from surface, indicating a strong damage. Exposure of HeLa cells to KAM significantly increased apoptotic death from $25 \mu \mathrm{g} / \mathrm{ml}$ and did not induce necrosis. The results displayed that cytotoxicity mechanism of KAM is the apoptosis. Apoptosis and necrosis are two fundamental types of cell death. Necrosis is cell rupture produced by excessive exogenous damage which is characteristic to inflammation, while apoptosis cell death is an active process regulated physiological, where is programmed cell death leading to a sequence of morphological changes by modifications of the cellular surface (22), which not showing inflammatory response (23). Apoptosis is a natural cell death which is considered the most important requirements of cancer drugs in treatments that induce tumor cells death.

Cervical cancer cells (HeLa) were the most sensitive to the toxic effect induced by KAM and the less sensitive were breast cancer cells (MCF-7 and MDA-MB-231), indicating that the cytotoxic effect of KAM depends of the type and stage of the cancer cells. HeLa cells are classified in an IVB stadium, are infected with human papilloma virus and are metastatic. It will very important to compare the toxic effect of KAM in other cervical cancer cells.

$1 \square$-hidroxibufalin, obtained from $F 10$, is a metabolite of the hydroxylation of the bufalin. This has anti-cancerigen properties in human leukemia and 
melanoma cells (15). Monohidroxibufalin, another hydroxylate form of bufalin, promoted apoptosis of HeLa cells (24), in accordance with our results. Finally, 3-dehydrocinobufagin has a potent anti-neoplasic activity, decrease osteosarcoma proliferation and induces apoptosis (25). Therefore, it will very interesting to isolate other compounds of KAM and to test their cytotoxic effect.

\section{Conclusion}

Leaves of $\mathrm{Km}$ are a rich source of bufadienolides. In the present study, nine known bufadienolides were identified from the methanol extract. Total bufadienolides from aerial part cause potent cytotoxic activity toward HeLa cell line. Our finding suggest for the first time that $K$. mortagei can act as an inducer of apoptosis of tumor cells.

\section{References}

1. Engel N, Oppermann C, Falodun A, Kragl A. Proliferative effects of five traditional Nigerian medicinal plant extracts on human breast and bone cancer cell lines. J. Ethnopharmacol. 2011; 137(2): 1003-1010.

2. U.S. Cancer Statistics Working Group. United States Cancer Statistics:

1999-2014 Incidence and Mortality Web-based Report. Atlanta: U.S. Department of Health and Human Services, Centers for Disease Control and Prevention and National Cancer Institute; 2017. Available at: www.cdc.gov/uscs.

3. Burchenal JH. The historical development of cancer chemotherapy. Semin Oncol.1977; 4(2): 135-146.

4. Newman GM. Natural products as sources of new drugs from 1981 to 2014. J Nat Prod. 2014; 79(3): 629-661.

5. Fulda S. Modulation of apoptosis by natural products for cancer therapy. Planta Med. 2010; 76 (11): 1075-1079.

6. Wu PL, Hsu YL, Wu TS, Bastow KF, Lee KH. Kalanchosides A-C, new cytotoxic bufadienolides from the aerial parts of Kalanchoe gracilis. Org. Lett. 2006; 8(23): 5207-5210.

7. Akinpelu DA Antimicrobial activity of Bryophyllum pinnatum leaves. Fitoterapia. 2000; 71(2): 193194.

8. Maurice M. Handbook of African medicinal plants. Boca Raton, Ann Arbor, London, Tokyo: CRC Press; 1993; pp 135-136.

9. Pal S, Chaudhuri NK. Studies on the anti-ulcer activity of a Bryophyllum pinnatum leaf extract in experimental animals. J. Ethnopharmacol. 1991; 33(1): 97- 102.

10. Nguelefack TB, Dimo T, Dongmo AB, Sontia B, Fotio AL, Watcho P. Cardiovascular effects of the n-butanol extract from Kalanchoe crenata leaves. Pharm. Biol. 2008; 46(4): 846-853.
11. Kamgang R, Mboumi RY, Fondjo AF, Tagne MAF, Mengue N'dille GPR, Yonkeu JN. Antihyperglycaemic potential of the water-ethanol extract of Kalanchoe crenata (Crassulaceae). J Nat Med. 2008; 62(1): 34-40.

12. Nguelefack TB, Nana $P$, Atsamo AD, Dimo $T$, Watcho $\mathrm{P}$, Dongmo AB. Analgesic and anticonvulsant effects of extracts from the leaves of Kalanchoe crenata Andrews Haworth (Crassulaceae). J. Ethnopharmacol. 2006; 106(1): 70- 75 .

13. Rossi-Bergmann B, Costa SS, Borges MBS, Da Silva SA, Noleto GR, Souza MLM. Immunosuppressive effect of the aqueous extract of Kalanchoe pinnata in mice. Phytother Res. 1994; 8: 399-402.

14. Kuo PC, Kuo TH, Su CR, Liou MJ, Wu TS. Cytotoxic principles and a-pyrone ringopening derivatives of bufadienolides from Kalanchoe hybrida. Tetrahedron. 2008; 64(15): 3392-3396.

15. Supratman U, Fujita T, Akiyama K, Hayashi H, Murakami A, Sakai H, Koshimizu K, Ohigashi H. Anti-tumor promoting activity of bufadienolides from Kalanchoe pinnata and $K$. daigremontiana x tubiflora. Biosci. Biotechnol. Biochem. 2001; 65(4): 947-949.

16. 16. Huang HC, Lin MK, Yang HL, Hseu YC, Liaw CC, Tseng YH, Tsuzuki M, Kuo YH. Cardenolides and bufadienolide glycosides from Kalanchoe tubiflora and evaluation of cytotoxicity. Planta Med. 2013; 79(14): 1362-1369.

17. Suffness M, Pezzuto JM. Assays related to cancer drug discovery. In: Hostettmann K, editor. Methods in plant biochemistry: assays for bioactivity. London: Academic Press, 1990; pp 71-133.

18. Yasuhara S, Zhu Y, Matsui T, Tipirneni N, Yasuhara Y, Kanemi M, Rosenzweig A, Martyn JA. Comparison of comet assay, electron microscopy, and flow cytometry for detection of apoptosis. J Histochem Cytochem. 2003; 51(7): 873-885.

19. Kamboj A, Rathour A, Kaur M. Bufadienolides and their medicinal utility: a review. Int J Pharm Pharm Sci. 2013; 58(2): 20-27.

20. Eren. Y. Mutagenic and cytotoxic activities of Limonium globuliferum methanol extracts. Cytotechnology. 2006; 68(5): 2115-24.

21. Arias I (2011). Evaluación de la actividad antitumoral de diferentes extractos de varias especies de Kalanchoe en una línea celular de cancer de próstata. Master dissertation, Instituto Politecnico NacionaL, Ciudad de Mexico, Mexico.

22. Mahata S, Maru S, Shukla S, Pandey A, Mugesh G, 
Das BC, Bharti AC. Anticancer property of Bryophyllum pinnata (Lam.) Oken. leaf on human cervical cancer cells. BMC Complement Altern Med. 2012; 12:15. 12:15. doi: 10.1186/1472-688212-15.

23. Kolodziejczyk-Czepas J, Nowak P, Wachowicz B, Piechocka J, Głowacki R, Moniuszko-Szajwaj B, Stochmal A. Antioxidant efficacy of Kalanchoe daigremontiana bufadienolide-rich fraction in blood plasma in vitro. Pharm Biol. 2016; 54(2): 31823188 .
24. Deng LJ, Hu LP, Peng QL, Yang XL, Bai LL, Yiu A, Li Y, Tian HY, Ye WC, Zhang DM. Hellebrigenin induces cell cycle arrest and apoptosis in human hepatocellular carcinoma HepG2 cells through inhibition of Akt. Chem Biol Interact. 2014; 219: 184-94. doi: 10.1016/j.cbi.2014.06.003.

25. Zhang LS, Nayaka K, Yoshida T, Kuroiwa Y (1991). Bufalin as a potent inducer of differentiation of human myeloid leukaemia cells. Biochem. Biophys. Res. Commun. 178(2): 686-693. 